\section{Phosphate Sorption of Calcined Materials Used as Components of Soilless Root Media Characterized in Laboratory Studies}

\author{
Rose A. Ogutu ${ }^{1}$ and Kimberly A. Williams ${ }^{2,3}$ \\ Department of Horticulture, Forestry, and Recreation Resources, Kansas \\ State University, 2021 Throckmorton Hall, Manhattan, KS 66506-5506
}

\author{
Gary M. Pierzynski² \\ Department of Agronomy, Kansas State University, Manhattan, KS 66506
}

Additional index words. adsorption envelopes, calcined clays, degree of phosphorus saturation, nutrient retention, soilless substrates, sorption isotherms

\begin{abstract}
Calcined materials may contribute enhanced phosphate $\left(\mathrm{PO}_{4}-\mathrm{P}\right)$ retention to soilless root media used in container production. Properties of nutrient retention vary greatly depending on the parent clay and calcining treatment. This research characterized $\mathrm{PO}_{4}-\mathrm{P}$ sorption of various calcined clay products, including low and regular volatile material (LVM and RVM) 2:1 attapulgite, montmorillonite, and illite clays at various particle sizes; 1:1 kaolin clays in powder form; and diatomaceous earth. Extractable $\mathrm{PO}_{4}-\mathrm{P}$, initial $\mathrm{pH}, \mathrm{PO}_{4}-\mathrm{P}$ sorption isotherms, amount of $\mathrm{P}$ sorbed as a function of solution pH at a fixed total concentration, and degree of phosphorus saturation were determined. Initial $\mathrm{pH}$ of the clays ranged from 3.7 to 8.7. Sorption isotherms were conducted with initial adsorbate concentrations ranging from 0 to $200 \mathrm{mg} \cdot \mathrm{L}^{-1} \mathrm{PO}_{4}-\mathrm{P}$ from $\mathrm{KH}_{2} \mathrm{PO}_{4}$. The calcined materials varied in their ability to sorb $\mathrm{PO}_{4}-\mathrm{P}$ and generally yielded $\mathrm{L}$-type isotherms, indicating that the adsorbate had relatively high affinity for the calcined material sample surface at low surface coverage. Some 2:1 calcined clays exhibited substantial $\mathrm{PO}_{4}-\mathrm{P}$ retention, but 1:1 calcined clays and diatomaceous earth did not. Clays with less moisture $(\mathrm{LVM})$ resulted in greater $\mathrm{PO}_{4}-\mathrm{P}$ sorption than those calcined at lower temperatures (RVM). Terra Green montmorillonites had higher $\mathrm{PO}_{4}-\mathrm{P}$ sorption than Terra Green attapulgites. Laboratory results indicated potential for substantive $\mathbf{P O}_{4}-\mathrm{P}$ retention by several of the calcined clay materials when used in container production. For most materials, $\mathrm{PO}_{4}-\mathrm{P}$ sorption did not show pronounced $\mathrm{pH}$ dependence, which suggests that $\mathrm{PO}_{4}-\mathrm{P}$ retention is not influenced by $\mathrm{pH}$-dependent charge within the $\mathrm{pH}$ range of container production.
\end{abstract}

Small volumes ( $2 \%$ to $20 \%)$ of a variety of calcined clay-type products are being used as components of soilless root media because of their potential to increase nutrient retention, air space, water retention, and bulk density of mixes used for container production in the

Received for publication 4 June 2008. Accepted for publication 3 Sept. 2008.

This research was funded by The Gloeckner Foundation and the Kansas Agricultural Experiment Station (KAES).

This manuscript has been assigned contribution No. 08-380-J from the KAES.

We gratefully acknowledge the following companies for providing calcined clay samples: Oil-Dri Production Co., Ripley, MS 38663; Engelhard Corp., Quincy, FL 32352; and Thiele Kaolin Co., Sandersville, GA 31082. We thank James Higgins for statistical advice.

The use of trade names in this publication does not imply endorsement by the KAES of products named nor criticism of similar ones not mentioned. ${ }^{1}$ Graduate Research Assistant.

${ }^{2}$ Professor.

${ }^{3}$ To whom reprint requests should be addressed; e-mail kwilliam@ksu.edu. greenhouse and nursery industries. Properties imparted by these materials are inherited from the parent clay or source, particle size distribution, and calcining process. High calcining temperatures result in expansion of the crushed clay to form a porous structure that is physically and chemically stable. The resulting granules provide aeration to the root medium and hold water internally within their pore structure.

Traditionally, the soil component of root media used for crop production in containers imparted significant $\mathrm{PO}_{4}-\mathrm{P}$ retention to the root medium. Marconi and Nelson (1984) showed that over $33 \%$ of the total $\mathrm{P}$ applied was leached from a soilless root medium containing 1 peatmoss: 1 vermiculite, but less than $5 \%$ was leached from a 1 sand: 1 soil: 1 peatmoss mix in a simulated plant-watering scheme. This difference, they concluded, was related to differences in $\mathrm{P}$ sorption by the various root medium components. Use of soil in container root media has fallen out of favor with commercial producers because it is relatively expensive compared with other components, variable from source to source, and must be pasteurized before use (Nelson, 2005).
Many types of calcined clay amendments may enhance $\mathrm{PO}_{4}-\mathrm{P}$ and water retention of soilless root media. Incorporation of 13\% (by volume) of a calcined clay has been shown to reduce the amount of $\mathrm{PO}_{4}-\mathrm{P}$ leached from pine bark-based container media by $73 \%$ in production of Loropelatum chinense var. rubrum R. Br. 'Blush' over a 16-week period (Ruter, 2003). Reduction in fertilizer and water use in poinsettia (Euphorbia pulcherrima Willd. ex Klotzsch) with incorporation of calcined clays has been shown (Catanzaro and Bhatti, 2005; Catanzaro et al., 2004). Owen et al. (2003) found that amending a pine bark root medium with $8 \%$ (by volume) calcined clay led to increased nutrient retention and water-buffering capacity in production of container-grown Cotoneaster dammeri C.K. Schneid 'Skogholm'. A root medium of 3 peat: 5 compost: 2 Turface (calcined arcillite clay; v/v) reduced $\mathrm{PO}_{4}-\mathrm{P}$ leaching by $70 \%$ compared with a control of 3 peat: 5 compost: 2 sand in production of black-eyed susan, Rudbekia hirta L. (Bugbee and Eliot, 1998). Because use of calcined clays offers potential to reduce environmental impact from $\mathrm{PO}_{4}-\mathrm{P}$ leaching during container production, $\mathrm{PO}_{4}-\mathrm{P}$ retention and other properties of a variety of calcined materials should be characterized.

Clay surfaces bear an electrical charge that is a function of permanent charge, variable charge, and inner and outer surface charge. The resultant particle charge is either created through isomorphic substitution, protonation and deprotonation reactions or partial charge as expressed through the polarity of atoms at the clay surface (Essington, 2004). The silicate minerals present in clays develop a $\mathrm{pH}$-dependent charge at the broken edges of the layer structure, which is a phenomenon that occurs in both $1: 1$ and $2: 1$ clay soils (Havlin et al., 2003).

Sorption of $\mathrm{PO}_{4}$ by clay minerals has been attributed to a $\mathrm{pH}$-dependent reaction of $\mathrm{PO}_{4}$ with calcium, iron (Fe), and aluminum ( $\mathrm{Al})$ in the clay (Havlin et al., 2003). Much of the P adsorption by soils can be attributed to chemisorptions involved in ligand exchange between $\mathrm{PO}_{4}-\mathrm{P}$ and hydroxyl ions at $\mathrm{Fe}$ and $\mathrm{Al}$ oxyhydroxides (Parfitt, 1978). pH-dependent $\mathrm{PO}_{4}-\mathrm{P}$ sorption by calcined clays has not been systematically investigated and it is not clear how the process of calcining changes the $\mathrm{PO}_{4}$ $\mathrm{P}$ sorption characteristics of clays.

The commercial calcining process results in low volatile material (LVM) or regular volatile material (RVM) moisture contents, depending on calcining temperatures. Calcining, generally, reduces the amount of water trapped between the clay's silicate sheets and also produces a very hard granule that, even when fully saturated with water, does not break apart easily. The first stage of calcining, known as fluid bed drying, reduces the clay moisture level from $40 \%$ to $45 \%$ down to $6 \%$ to $9 \%$ using temperatures of $\approx 120$ to 176 ${ }^{\circ} \mathrm{C}$, resulting in RVM clays. The LVM clays have even lower moisture content of $0 \%$ to $3 \%$, which is achieved by secondary calcining at temperatures in the range of 460 to 800 ${ }^{\circ} \mathrm{C}$ (Moll and Goss, 1997). Heating the clays 
causes aggregation of particles that optimizes sorbtivity by creating a stable porous internal structure. Calcining reduces the exchange capacity of the clays, but surface binding and internal pores maintain some nutrient retention capacity. X-ray diffraction studies on a 2:1 Ca-montmorillonite clay showed that heat treatment of 200 to $400{ }^{\circ} \mathrm{C}$ completely collapsed the interlayer, incorporating interlayer cations into the tetrahedral or unoccupied octahedral sheets (Bray et al., 1998). Noyan et al. (2006) evaluated the specific surface area, specific micromesopore volume, total surface acidity, and adsorption equilibrium constant of original and heated samples of a bentonite clay from Turkey. The specific area, micromesopore volume, and total surface acidity stayed constant as temperature increased to $450{ }^{\circ} \mathrm{C}$ and then decreased. Total surface acidity, in general, declined with increasing temperatures. The most acidic sites, however, increased with heating and especially at temperatures of dehydration $\left(100\right.$ to $\left.550{ }^{\circ} \mathrm{C}\right)$ and dehydroxylation $\left(550\right.$ to $\left.700{ }^{\circ} \mathrm{C}\right)$. Calcining temperatures for maximizing sorbtivity, generally, do not exceed the dehydration interval. Noyan et al. (2006) concluded that the decomposition of the 2:1 layers of the clay and collapsing of micro- and mesopores by intraand interparticle sintering caused a rapid decrease in specific surface area and specific micromesopore volume as the temperature increased.

Diatomaceous earth (DE) is not derived from clay, but consists of granules mined from sedimentary rock deposits resulting from accumulation of amorphous silica comprising the cell walls of dead, single-celled aquatic organisms called diatoms (Handreck and Black, 2002). The usual commercial function of DE is as an absorbent. Although some commercial growers are using this material as a root medium component, it is not expected to sorb $\mathrm{PO}_{4}-\mathrm{P}$ because it lacks charged sorption sites.

Phosphate retention properties of clays after calcining are generally unknown, and the role of $\mathrm{pH}$-dependent edge charge in the $\mathrm{PO}_{4}-\mathrm{P}$ retention of calcined materials is untested. In addition, the calcined materials themselves may provide $\mathrm{PO}_{4}-\mathrm{P}$ and other nutrients as fertilizer if natural levels are high. Therefore, this research characterizes several calcined clay materials and diatomaceous earth as a basis to evaluate their potential to reduce $\mathrm{PO}_{4}-\mathrm{P}$ leached during container production when used as components of soilless root media. Specifically, we 1) determined inherent $\mathrm{PO}_{4}-\mathrm{P}$ by extraction and total $\mathrm{P}$ present in the mineral; 2) determined initial $\mathrm{pH}$ of unaltered samples; 3) characterized $\mathrm{PO}_{4}-\mathrm{P}$ sorption at natural $\mathrm{pH} ; 4$ ) developed $\mathrm{PO}_{4}-\mathrm{P}$ adsorption envelopes under variable $\mathrm{pH}$ conditions to establish the role of $\mathrm{pH}$-dependent edge charge on $\mathrm{PO}_{4}-\mathrm{P}$ retention; and 5) determined the initial degree of phosphorus saturation of calcined materials.

\section{Materials and Methods}

The tested calcined materials are commercially available (Table 1 ). The test materials included various particle sizes of 2:1 clays of attapulgite (Attasorb; Engelhard Corp., Quincy, FL) calcined at two temperatures, RVM and LVM: LVM montmorillonite mined in Mississippi and LVM attapulgite mined in Georgia (Terra Green; Oil-Dri Prod. Co., Ripley, MS) and montmorillonite + illite
(Turface; Profile Products LLC, Buffalo Grove, IL); calcined 1:1 clays (Thiele Kaolin Co., Sandersville, GA) in powder form; and diatomaceous earth (Diatomite Eagle-Picher Minerals, Inc., Reno, NV). For ease of reference, the test materials were coded using trade name, temperature treatment, and particle size as mesh size designated by the manufacturer (Table 1). The materials were tested as received from the manufacturer.

Particle size distribution. Particle size distribution was determined by dry sieving. The sieving process was carried out using woven analytical precision sieves (USA standard testing sieves, ASTME specification; Fisher Scientific Co., Columbia, MD). Dry test materials were weighed to $1000 \mathrm{~g}$ and passed through a stack of eight sieves ranging from 5 mesh (4.0-mm nominal sieve opening) to 80 mesh (180- $\mu \mathrm{m}$ sieve opening) that were arranged in order of size with the smallest sieve at the bottom of the stack. Samples were uniformly shaken on a circular motion shaker set at $2.2 g_{n}$ for $5 \mathrm{~min}$. Sample recovered in each sieve was weighed and the proportions calculated as a percentage of the whole test sample (Table 2) averaged across three replications.

pH measurements. The $\mathrm{pH}$ was measured on a slurry consisting of $5 \mathrm{~cm}^{3}$ test material to $10 \mathrm{~mL}$ deionized water. Mixtures were thoroughly stirred and allowed to settle for 10 min before reading $\mathrm{pH}$ (Oyster $\mathrm{pH}$ meter; Extech Instr. Waltham, MA) at $27{ }^{\circ} \mathrm{C}$. The data were analyzed using PROC GLM in SAS ver. 9.1 (SAS Institute, 2002) with three replicates per material.

Phosphorus extraction. Naturally occurring $\mathrm{P}$ present in the calcined materials was

Table 1. Calcined material trade names, sample codes, and descriptions of test materials provided by their sources.

\begin{tabular}{|c|c|c|c|c|}
\hline Trade name & $\begin{array}{l}\text { Volatile material } \\
\text { characterization }^{z}\end{array}$ & $\begin{array}{c}\text { Mesh size } \\
\text { (standard US mesh) }\end{array}$ & Assigned code & Test material description ${ }^{y}$ \\
\hline Attasorb $^{x}$ & LVM & $8 / 16$ & A-LVM-8/16 & $1 \%$ to $10 \%$ quartz $90 \%$ to $99 \%$ Fuller's earth ${ }^{\mathrm{w}}$; is a hydrous \\
\hline Attasorb $^{x}$ & RVM & $8 / 16$ & A-RVM-8/16 & magnesium alumina silicate attapulgite; the deposits are on the \\
\hline Attasorb $^{\mathrm{x}}$ & LVM & $24 / 28$ & A-LVM-24/48 & Florida-Georgia border \\
\hline Attasorb $^{x}$ & RVM & $24 / 48$ & A-RVM-24/28 & \\
\hline Terra Green attapulgite ${ }^{v}$ & LVM & $24 / 48$ & T-A-24/28 & $10 \%$ to $20 \%$ quartz $80 \%$ to $90 \%$ Fuller's \\
\hline Terra Green attapulgite ${ }^{v}$ & LVM & $16 / 30$ & $\mathrm{~T}-\mathrm{A}-16 / 30$ & earth $^{\mathrm{w}}$; from Georgia mines \\
\hline Terra Green attapulgite ${ }^{v}$ & LVM & $5 / 20$ & $\mathrm{~T}-\mathrm{A}-5 / 20$ & \\
\hline Terra Green montmorillonite ${ }^{\mathrm{v}}$ & LVM & $24 / 48$ & $\mathrm{~T}-\mathrm{M}-24 / 28$ & $7 \%$ to $10 \%$ quartz $90 \%$ to $93 \%$ montmorillonite; \\
\hline Terra Green montmorillonite ${ }^{\mathrm{v}}$ & LVM & $16 / 30$ & T-M-16/30 & from Mississippi mines \\
\hline Terra Green montmorillonite ${ }^{v}$ & LVM & $5 / 20$ & $\mathrm{~T}-\mathrm{M}-5 / 20$ & \\
\hline Turface $^{\mathrm{u}}$ & & & Turface & $\begin{array}{l}\text { Product of calcining a smectite clay at temperatures ranging } \\
\quad \text { from } \approx 540{ }^{\circ} \mathrm{C} \text { to } \approx 1100{ }^{\circ} \mathrm{C}\end{array}$ \\
\hline Kaolin Hydrous ${ }^{t}$ & & Powder & K-Hyd-P & Hydrous kaolin \\
\hline Kaorock $^{t}$ & & Powder & K-LSA-P & Low surface area metakaolin \\
\hline Kaocal $^{\text {t }}$ & & Powder & K-P & Full calcined at $980{ }^{\circ} \mathrm{C}$ \\
\hline Kaocal LA ${ }^{t}$ & & Powder & K-HSA-P & High surface area metakaolin calcined at less than $980^{\circ} \mathrm{C}$ \\
\hline Diatomite $^{\mathrm{s}}$ & & & Diatomite & $\begin{array}{l}\text { Diatomaceous earth consists of fossilized remains of diatoms, } \\
\text { typical chemical composition of diatomaceous earth is } 86 \% \\
\text { silica, } 5 \% \text { sodium, } 3 \% \text { magnesium, and } 2 \% \text { iron }\end{array}$ \\
\hline
\end{tabular}

${ }^{\mathrm{z}} \mathrm{LVM}=$ low volatile material; clays calcined at $\approx 470{ }^{\circ} \mathrm{C} ; \mathrm{RVM}=$ regular volatile material; clays calcined at $\approx 180{ }^{\circ} \mathrm{C}$.

${ }^{\mathrm{y}}$ Test material description was given in material safety data sheets (MSDS) from source unless stated otherwise.

${ }^{x}$ Englehard Corp., Quincy, FL.

wFuller's earth usually has a high magnesium oxide content. Two varieties of Fuller's earth are mined, mainly in the southeastern states of the United States. These comprise the minerals montmorillonite or palygorskite (attapulgite) or a mixture of the two; some of the other minerals that may be present in fuller's earth deposits are calcite, dolomite, and quartz.

voil-Dri Prod. Co., Ripley, MS.

uProfile Products LLC, Buffalo Grove, IL.

tThiele Kaolin Co., Sandersville, GA.

${ }^{\text {s}}$ Eagle-Picher Minerals, Inc., Reno, NV. 
Table 2. Particle size distribution of the 16 test materials.

\begin{tabular}{|c|c|c|c|c|c|c|c|c|c|}
\hline \multirow[b]{2}{*}{ Code $^{z}$} & Sieve no. & No. 5 & No. 8 & No. 10 & No. 18 & No. 20 & No. 35 & No. 60 & No. 80 \\
\hline & $\begin{array}{c}\text { Mesh size } \\
\text { (standard US } \\
\text { mesh) }\end{array}$ & $4.0 \mathrm{~mm}$ & $2.38 \mathrm{~mm}$ & $2.00 \mathrm{~mm}$ & $1.00 \mathrm{~mm}$ & $0.85 \mu \mathrm{m}$ & $0.5 \mu \mathrm{m}$ & $0.25 \mu \mathrm{m}$ & $0.18 \mu \mathrm{m}$ \\
\hline & & \multicolumn{8}{|c|}{ Percent by weight ${ }^{y}$} \\
\hline A-LVM-8/16 & $8 / 16$ & & 6 & 39 & 55 & & & & \\
\hline A-RVM-8/16 & $8 / 16$ & & 3 & 40 & 57 & & & & \\
\hline A-LVM-24/48 & $24 / 28$ & & & & & 1 & 73 & 26 & \\
\hline A-RVM-24/48 & $24 / 48$ & & & & 1 & 2 & 71 & 25 & 1 \\
\hline T-A-24/28 & $24 / 48$ & & & & & 1 & 77 & 21 & \\
\hline T-M-24/28 & $24 / 28$ & & & & 1 & 4 & 78 & 17 & \\
\hline T-A-16/30 & $16 / 30$ & & & & 77 & 11 & 11 & 1 & \\
\hline T-M-16/30 & $16 / 30$ & & & & 44 & 20 & 35 & 1 & \\
\hline $\mathrm{T}-\mathrm{A}-5 / 20$ & $5 / 20$ & 2 & 37 & 17 & 32 & 2 & 8 & 2 & \\
\hline T-M-5/20 & $5 / 20$ & 3 & 52 & 14 & 29 & 1 & 1 & & \\
\hline Turface & & 1 & 42 & 24 & 29 & 4 & & & \\
\hline K-Hyd-P & Powder & & & & & & & & 100 \\
\hline K-LSA-P & Powder & & & & & & & & 100 \\
\hline K-P & Powder & & & & & & & & 100 \\
\hline K-HSA-P & Powder & & & & & & & & 100 \\
\hline $\begin{array}{l}\text { Diatomaceous } \\
\text { earth }\end{array}$ & & 3 & 84 & 8 & 5 & & & & \\
\hline
\end{tabular}

${ }^{\mathrm{z}} \mathrm{LVM}=$ low volatile material; clays calcined at $\approx 470{ }^{\circ} \mathrm{C} . \mathrm{RVM}=$ regular volatile material; clays calcined at $\approx 180{ }^{\circ} \mathrm{C}$

yPercent (by weight) of given particle size.

evaluated with three methods: dilute acid extraction, Mehlich III (M3) extraction, and salicylic-sulfuric digestion. For dilute acid extraction, the weight of $5 \mathrm{~cm}^{3}$ of each test material was determined and measured into 50-mL Erlenmeyer flasks. Thirty milliliters of acid extractant consisting of $0.5 \mathrm{~N} \mathrm{HCl}$ and $0.2 \mathrm{~N} \mathrm{H}_{2} \mathrm{SO}_{4}$ was added. The flasks were placed on a circular motion shaker at $2 g_{\mathrm{n}}$ for $10 \mathrm{~h}$ at $26.0 \pm 2{ }^{\circ} \mathrm{C}$, and after $10 \mathrm{~h}$, the supernatant was transferred into $50-\mathrm{mL}$ centrifuge tubes and centrifuged at $310 g_{\mathrm{n}}$ for 5 min. Solution $\mathrm{pH}$ was adjusted by drop-wise addition of $5 \mathrm{M} \mathrm{NaOH}$ using p-nitrophenol as the indicator until the color of the sample just changed from colorless to yellow (Bender and Wood, 2000). Phosphate in the supernatant was then analyzed using the colorimetric method of Murphy and Riley (1962) on an ultraviolet/VIS spectrophotometer (PerkinElmer, Norwalk, CT). The experimental design was completely random (CRD) and each treatment was replicated three times. The data were analyzed using PROC GLM in SAS ver. 9.1 (SAS Institute, 2002).

Mehlich III (M3) extraction solution contained $0.2 \mathrm{~N}$ acetic acid, $0.25 \mathrm{~N} \mathrm{NH}_{4} \mathrm{NO}_{3}$, $0.015 \mathrm{~N} \mathrm{NH}_{4} \mathrm{~F}, 0.013 \mathrm{~N} \mathrm{HNO}_{3}$, and $0.001 \mathrm{~N}$ EDTA (Sen Tran and Simard, 1993). Mehlich III extractable P (1:5 test material:solution ratio) was analyzed with a Lachat-FIA system (Lachat FIA 800 series, Loveland, CO) The M3 procedure uses a strong acid extractant and estimates available $\mathrm{P}$ in acid soils. Two replications of each test material were run.

Finally, total $\mathrm{P}$ of the test materials was analyzed by colorimetric procedures after salicylic-sulfuric acid digestion (Bremner and Mulvaney, 1982; U.S. Environmental Protection Agency, 1984). The extract was analyzed by colorimetric procedures using the Technicon Auto Analyzer II (Technicon Industrial Systems, Tarrytown, NY). Two replications of each test material were run.
$\mathrm{PO}_{4}-\mathrm{P}$ sorption isotherms. To characterize and compare $\mathrm{P}$ sorption of the calcined products, sorption isotherms were created for each test material. An amount equal in weight to $5 \mathrm{~cm}^{3}$ volume was measured into a $50-\mathrm{mL}$ Erlenmeyer flask. Samples were equilibrated for $18 \mathrm{~h}$ with $30 \mathrm{~mL}$ of solution containing initial adsorbate concentrations of $0,10,25$, 50,100 and $200 \mathrm{mg} \cdot \mathrm{L}^{-1} \mathrm{PO}_{4}-\mathrm{P}$ prepared from $\mathrm{KH}_{2} \mathrm{PO}_{4}$ using deionized water. Treatment structure was factorial with three replicates of each material for each $\mathrm{P}$ concentration and experimental design was CRD. Flasks were placed on a circular motion shaker at $2 g_{n}$ for $10 \mathrm{~h}$ at $25 \pm 2{ }^{\circ} \mathrm{C}$ and then centrifuged at 310 $g_{\mathrm{n}}$ for $5 \mathrm{~min}$. Equilibrium $\mathrm{P}$ concentration and $\mathrm{pH}$ of the supernatant were determined using colorimetric procedures (Chapman and Pratt, 1961; Murphy and Riley, 1962) and the $\mathrm{pH}$ meter described previously. The amount of $\mathrm{P}$ adsorbed by the clay sample was calculated as follows:

$$
\mathrm{Q}=\mathrm{v}\left(\mathrm{C}_{\mathrm{i}}-\mathrm{C}_{\mathrm{f}}\right) / \mathrm{m}
$$

where $Q$ is the amount of $\mathrm{PO}_{4}-\mathrm{P}$ sorbed ( $\mathrm{mg} \cdot \mathrm{kg}^{-1} \mathrm{P}$ calcined material), $\mathrm{v}$ is the liquid sample volume $(\mathrm{L}), \mathrm{C}_{\mathrm{i}}$ is the initial concentration of $\mathrm{PO}_{4}-\mathrm{P}$ in the solution containing adsorbate $\left(\mathrm{mg} \cdot \mathrm{L}^{-1}\right), \mathrm{C}_{f}$ is the final (equilibrium) concentration of $\mathrm{PO}_{4}-\mathrm{P}$ in the supernatant solution $\left(\mathrm{mg} \cdot \mathrm{L}^{-1}\right)$, and $\mathrm{m}$ is the amount of the test material (kg, dry weight basis; Essington, 2004). Phosphate sorbed, Q, was presented as $\mathrm{g} \cdot \mathrm{m}^{-3}$ for ease of application to greenhouse container production.

The Freundlich equation, although considered purely empirical in nature, has been extensively used to describe ion adsorption by soils (Aslam et al., 2000; Chaudhry et al., 2003; Obaid-ur-Rehman et al., 2004; Sposito, 1980). The sorption isotherms were examined by modified Freundlich equations proposed by Le Mare (1982). The form of the modified Freundlich model is as follows:

$$
\mathrm{P}=\mathrm{a} \mathrm{C}^{\mathrm{b} / \mathrm{a}}
$$

where $\mathrm{P}$ is quantity of sorbate $(\mathrm{g})$ per unit volume $\left(\mathrm{m}^{3}\right)$ of adsorbent, $\mathrm{C}$ is equilibrium solution concentration $\left(\mathrm{mg} \cdot \mathrm{L}^{-1}\right)$ of the adsorbate, "a" is the amount of $\mathrm{PO}_{4}-\mathrm{P}$ sorbed $\left(\mathrm{g} \cdot \mathrm{m}^{-3}\right)$ when the concentration $\mathrm{C}$ is $1 \mathrm{mg} \cdot \mathrm{L}^{-1}$, and " $b$ " is the buffer power defined by the slope of the sorption curve at the point where $\mathrm{P} / \mathrm{C}=1 \mathrm{~L} \cdot \mathrm{m}^{-3}$.

The main advantage of this equation is that " $a$ " and " $b$ " are the amount of P sorbed and buffer capacities, respectively, at the same point on the curve where $\mathrm{C}=1 \mathrm{mg} \cdot \mathrm{L}^{-1}$, and this point is the same for all the test materials. In our research, the parameters "a" and "b" were estimated by regression of the logarithmic form of the data obtained from sorption isotherms. Therefore, a plot of $\log \mathrm{P}(\mathrm{y}$-axis variable) against $\log \mathrm{C}(\mathrm{x}$-axis variable) yields a straight line with slope $b / a$ and y-intercept of log a.

$$
\log \mathrm{P}=\log \mathrm{a}+\mathrm{b} / \mathrm{a} \log \mathrm{C}
$$

From the Freundlich equation the parameter, "a" could be considered as a capacity factor and was referred to as $\mathrm{P}$ sorption capacity; this implies that a material having a larger "a" value has a larger sorption capacity than one with a smaller "a" value. Therefore, "a" value estimates were used to differentiate the $\mathrm{P}$ sorption capacities of calcined materials. The Freundlich equation does not predict or include a maximum adsorption capacity, but it is reliable with low solution $\mathrm{P}$ concentrations (Havlin et al., 2003). R values were determined for each Freundlich equation.

Adsorption envelopes. Adsorption envelopes were created to determine the amount of $\mathrm{P}$ adsorbed as a function of solution $\mathrm{pH}$ at the fixed total $\mathrm{P}$ concentration of $600 \mathrm{mg} \cdot \mathrm{L}^{-1}$. An amount equal in weight to $5 \mathrm{~cm}^{3}$ volume of eight test materials, A-LVM-8/16, ARVM-24/28, T-A-24/48, T-M-24/28, T-M$5 / 20$, K-LSA-P, Turface, and Diatomite (Table 1), were equilibrated for $10 \mathrm{~h}$ at $25^{\circ} \mathrm{C}$ with $25 \mathrm{~mL} \mathrm{KNO}_{3}$. A $2.5-\mathrm{mL}$ aliquot of $600 \mathrm{P}$ $\mathrm{mg} \cdot \mathrm{L}^{-1}$ from $\mathrm{KH}_{2} \mathrm{PO}_{4}$ was added and $\mathrm{pH}$ adjusted to ranges of 2 to 10 at intervals of one unit using additions of $0.1 \mathrm{M} \mathrm{HNO}_{3}$ or $0.1 \mathrm{M} \mathrm{KOH}$. Samples were centrifuged as described previously, decanted, filtered, and analyzed for $\mathrm{PO}_{4}-\mathrm{P}$ concentration as described previously. The experimental design was CRD with three replications of each treatment. Eight test materials were subjected to nine $\mathrm{pH}$ levels.

Degree of phosphorus saturation. Degree of $\mathrm{P}$ saturation (DPS) estimates how close the test material is to being saturated with $\mathrm{PO}_{4}-\mathrm{P}$ (Sharpley, 1995). The DPS of the calcined materials was determined to compare the level of initial saturation with $\mathrm{PO}_{4}-\mathrm{P}$ of each material's exchange sites. A DPS index (Pote et al., 1999) was created from soil test phosphorus (STP) determined by M3 extraction and a phosphorus sorption index (PSI) calculated from a single point isotherm (Bache and Williams, 1971; Sims et al., 2002). To establish the PSI, $30 \mathrm{~mL}$ of a 500 
$\mathrm{mg} \cdot \mathrm{L}^{-1} \mathrm{PO}_{4}-\mathrm{P}$ sorbate solution from $\mathrm{KH}_{2} \mathrm{PO}_{4}$ was added to $5 \mathrm{~cm}^{3}$ of test material, equilibrated on a shaker for $18 \mathrm{~h}$ at $25 \pm 2{ }^{\circ} \mathrm{C}$, and centrifuged as described previously. Phosphate was determined as described previously (Murphy and Riley, 1962). The PSI was calculated using the equation:

$$
\text { PSI }=\mathrm{q}(\log \mathrm{C})^{-1}
$$

where $\mathrm{q}$ is the amount of $\mathrm{P}$ sorbed $\left(\mathrm{mg} \cdot \mathrm{kg}^{-1}\right)$ and $\mathrm{C}$ is the equilibrium solution $\mathrm{P}$ concentration $\left(\mathrm{mg} \cdot \mathrm{L}^{-1}\right)$. The second step involved estimating DPS STP using the ratio of STP to (PSI + STP) and multiplying by 100 : DPS $_{\text {STP }}$ $(\%)=\left\{\mathrm{STP}\left(\mathrm{mg} \cdot \mathrm{kg}^{-1}\right) /\left[\mathrm{PSI}+\mathrm{STP}\left(\mathrm{mg} \cdot \mathrm{kg}^{-1}\right)\right]\right\}$ $\times 100$.

\section{Results and Discussion}

Particle size distribution, $p H$, and bulk density. Characterization of particle size distribution of the test materials is summarized in Table 2. Results follow U.S. standard mesh sizes.

Attasorb materials were alkaline with $\mathrm{pH}$ ranging from 8.2 to 8.7 (Table 3). Terra Green montmorillonites were acidic with $\mathrm{pH}$ ranging from 3.8 to 4.3 , whereas Terra Green attapulgites were less acidic with $\mathrm{pH}$ ranging from 5.6 to 6.2. Turface and diatomite had $\mathrm{pH}$ values of 6.1 and 5.1, respectively (Table 3). The various calcined materials exhibited a wide range of $\mathrm{pH}$. It is important for a grower to be aware of the $\mathrm{pH}$ levels that root medium components contribute to a mix because they may influence nutrient retention and management during production.

Calcined materials have lower bulk density (less than $1 \mathrm{~g} \cdot \mathrm{cm}^{3}$ ) compared with most mineral soils, which have bulk densities between 1 and $2 \mathrm{~g} \cdot \mathrm{cm}^{3}$ (Hillel, 2004). Lower bulk densities after calcining indicate increased porosity of the test material. Compared with Attasorb and Terra Green materials, DE exhibited greater porosity (Table 3 ). Compared with clay soils, the granular test materials have the advantage of adding stable pore space to soilless root media, which contributes to beneficial physical properties in container production.

Phosphorus content of calcined materials. Total native $\mathrm{P}$ present in the materials was relatively high in the Attasorb and Terra Green attapulgites (700 to $2800 \mathrm{mg} \cdot \mathrm{kg}^{-1}$; Table 3). This significant amount of $\mathrm{PO}_{4}-\mathrm{P}$ may provide some $\mathrm{P}$ fertilizer during production and/or remain in the container after the production cycle concludes. Kaolin test materials contained between 580 and $670 \mathrm{mg} \cdot \mathrm{kg}^{-1}$ $\mathrm{P}$, whereas diatomite and Terra Green montmorillonite had the least native $\mathrm{P}$ at between 250 and $370 \mathrm{mg} \cdot \mathrm{kg}^{-1} \mathrm{P}$ (Table 3). High levels of native $\mathrm{P}$ in the calcined materials might be expected to reduce $\mathrm{PO}_{4}-\mathrm{P}$ sorption capacity.

Phosphorus was extracted from the test materials using two procedures, an acid ex- traction and the M3 test, which was developed in North Carolina for routine analysis of $\mathrm{P}$, potassium, calcium, magnesium, sodium, and micronutrients in acid soils. The two extraction methods yielded substantially different $\mathrm{P}$ contents (Table 3 ). Different chemical extractants are designed for soils depending on their chemical characteristics. Attapulgite test materials from two sources, which have $\mathrm{pH}$ ranging from 5.6 to 8.7, resulted in greater $\mathrm{P}$ extracted by $0.5 \mathrm{~N} \mathrm{HCl}+0.2 \mathrm{~N} \mathrm{H}_{2} \mathrm{SO}_{4}$ than the M3 procedure, but the opposite was true for kaolinite test materials, which had $\mathrm{pH}$ of 4.5 to 5.3. The evolution of carbon dioxide during acid extraction of the Attasorb materials indicated a possible presence of free $\mathrm{CaCO}_{3}$, which, in combination with the higher $\mathrm{pH}$, suggested that the $\mathrm{M} 3$ test is not ideal for these calcareous clays. Results of the M3 test showed the influence of particle size on available $\mathrm{PO}_{4}-\mathrm{P}$ with smaller sizes of the same material yielding more $\mathrm{PO}_{4}-\mathrm{P}$. Kaolinite materials KLSA and K-P yielded the most $\mathrm{PO}_{4}-\mathrm{P}, 460$ and $116 \mathrm{mg} \cdot \mathrm{kg}^{-1} \mathrm{PO}_{4}-\mathrm{P}$, respectively, from the M3 procedure. Attasorb RVM materials yielded more available $\mathrm{PO}_{4}-\mathrm{P}$ compared with LVM materials (45 to $92 \mathrm{mg} \cdot \mathrm{kg}^{-1} \mathrm{P}$ and 6 to $14 \mathrm{mg} \cdot \mathrm{kg}^{-1} \mathrm{P}$, respectively).

$\mathrm{PO}_{4}-\mathrm{P}$ isotherms. The isotherms, which are L-type according to classification of sorption isotherms by shape, indicate monomolecular adsorption of $\mathrm{PO}_{4}-\mathrm{P}$ (Figs. 1A, 2A,

Table 3. Bulk density, pH, amount of P extracted from test materials from three different extraction procedures, degree of phosphorus saturation, $\mathrm{P}$ sorption index, and P sorption capacity, and buffer capacity calculated from the modified Freundlich equation.

\begin{tabular}{|c|c|c|c|c|c|c|c|c|c|}
\hline $\begin{array}{l}\text { Test material } \\
\text { code name }\end{array}$ & $\mathrm{pH}^{\mathrm{z}}$ & $\begin{array}{l}\text { Bulk density } \\
\left(\mathrm{g} \cdot \mathrm{cm}^{-3}\right)\end{array}$ & $\begin{array}{l}\text { Total } \mathrm{P}^{\mathrm{y}, \mathrm{x}} \\
\left(\mathrm{mg} \cdot \mathrm{kg}^{-1}\right)\end{array}$ & $\begin{array}{c}\mathrm{P}^{\mathrm{w}} \\
\left(\mathrm{mg} \cdot \mathrm{kg}^{-1}\right)\end{array}$ & $\mathrm{P}^{\mathrm{v}, \mathrm{x}}\left(\mathrm{mg} \cdot \mathrm{kg}^{-1}\right)$ & $\begin{array}{l}\text { Degree of } \\
\text { phosphorus } \\
\text { saturation } \\
(\mathrm{DPS} ; \%)^{\mathrm{u}}\end{array}$ & $\begin{array}{c}\text { P sorption } \\
\text { index }(\mathrm{PSI})^{\mathrm{t}} \\
\left(\mathrm{q}^{*} \log \mathrm{C}^{-1}\right)\end{array}$ & $\begin{array}{c}\text { Amount } \\
\text { adsorbed }(\mathrm{P} \\
\text { sorption } \\
\text { capacity) "a" } \\
\left(\mathrm{g} \cdot \mathrm{m}^{-} 3\right)^{\mathrm{s}}\end{array}$ & $\begin{array}{l}\text { Buffer capacity } \\
\text { "b" }\left(\mathrm{L} \cdot \mathrm{m}^{-3}\right)^{\mathrm{r}}\end{array}$ \\
\hline A-LVM-24/48 & 8.4 & 0.75 & $1,076 \pm 198$ & 306 & $14 \pm 0.5$ & 0.9 & 1,476 & 495 & 241 \\
\hline A-RVM-24/28 & 8.5 & 0.76 & $737 \pm 156$ & 534 & $92 \pm 0.5$ & 6.8 & 1,265 & 230 & 106 \\
\hline A-LVM-8/16 & 8.2 & 0.76 & $2,790 \pm 147$ & 231 & $6 \pm 0.5$ & 0.4 & 1,231 & 320 & 150 \\
\hline A-RVM-8/16 & 8.7 & 0.80 & $1,770 \pm 14$ & 146 & $45 \pm 0.5$ & 3.8 & 1,140 & 220 & 102 \\
\hline A-LVM-5/25 & 8.4 & 0.76 & $1,227 \pm 150$ & 245 & $20 \pm 0.5$ & 1.4 & 1,354 & - & - \\
\hline T-A-24/28 & 5.7 & 0.58 & $1,739 \pm 212$ & 166 & $70 \pm 0.5$ & 7.2 & 893 & 210 & 97 \\
\hline T-A-16/30 & 5.6 & 0.52 & $1,560 \pm 97$ & 250 & $34 \pm 0.5$ & 2.9 & 1,130 & 240 & 103 \\
\hline $\mathrm{T}-\mathrm{A}-5 / 20$ & 6.2 & 0.67 & $1,947 \pm 88$ & 60 & $39 \pm 0.5$ & 3.2 & 1,156 & 250 & 114 \\
\hline T-M-24/28 & 4.3 & 0.72 & $377 \pm 11$ & 37 & $107 \pm 2.0$ & 7.7 & 1,285 & 425 & 202 \\
\hline T-M-16/30 & 4.0 & 0.71 & $263 \pm 31$ & 19 & $65 \pm 2.0$ & 4.0 & 1,556 & 590 & 295 \\
\hline T-M-5/20 & 3.8 & 0.77 & $351 \pm 21$ & 78 & $35 \pm 3.5$ & 1.8 & 1,838 & 700 & 357 \\
\hline Turface & 6.1 & 0.22 & $345 \pm 22$ & 22 & $27 \pm 3.0$ & 4.1 & 637 & 115 & 48 \\
\hline K-Hyd-P & 4.2 & 0.19 & $264 \pm 40$ & 0.1 & $4 \pm 0.0$ & 0.5 & 736 & 100 & 36 \\
\hline K-LSA-P & 4.6 & 0.15 & $656 \pm 17$ & 47 & $460 \pm 20$ & 27.7 & 1,199 & 120 & 48 \\
\hline K-P & 5.3 & 0.12 & $652 \pm 15$ & 7 & $116 \pm 0.5$ & 13.9 & 725 & 70 & 25 \\
\hline K-HSA-P & 4.5 & 0.26 & $581 \pm 21$ & 23 & $93 \pm 1.0$ & 4.8 & 1,832 & 130 & 53 \\
\hline Diatomite & 5.1 & 0.37 & $259 \pm 52$ & 34 & $24 \pm 3.0$ & 4.8 & 475 & 28 & 10 \\
\hline $\begin{array}{l}\text { Diatomite } \\
\quad(\text { calcined })\end{array}$ & 5.4 & 0.34 & $179 \pm 4$ & 28 & $20 \pm 1.5$ & 4.7 & 398 & - & - \\
\hline $\mathrm{LSD}_{0.05^{\mathrm{q}}}$ & 0.44 & 0.014 & & 36.7 & & & & 56.5 & 71.3 \\
\hline
\end{tabular}

${ }^{\mathrm{z}} \mathrm{pH}$ measurements were taken on 1:2 (v/v) test material:deionized water.

${ }^{\mathrm{y}}$ From salicyclic-sulphuric acid digest.

${ }^{x}$ Mean \pm SD $(\mathrm{n}=2)$.

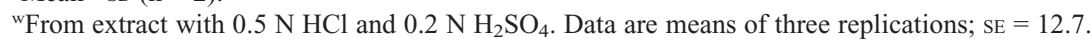

${ }^{\mathrm{v} F r o m ~ M e h l i c h ~ I I I ~ e x t r a c t i o n ~ p r o c e d u r e . ~}$

unegree of phosphorus saturation (DPS) estimated from PSI and Mehlich III P.

${ }^{\mathrm{t}}$ Calculated from a single-point isotherm based on $500 \mathrm{mg} \cdot \mathrm{L}^{-1} \mathrm{PO}_{4}-\mathrm{P}$ concentration.

sFrom modified Freundlich model; "a" value estimates P sorption capacity.

rFrom modified Freundlich model; "b" value estimates buffer power defined by the slope of the sorption curve at the point where quantity of sorbate (P)/ equilibrium solution concentration $(\mathrm{C})=1 \mathrm{~L} \cdot \mathrm{m}^{-3}$.

${ }^{\mathrm{q}} \mathrm{LSD}=$ least significant difference. Differences between means greater than the LSD indicate significant differences at $P<0.05$. Different letters indicate statistically significant differences. 

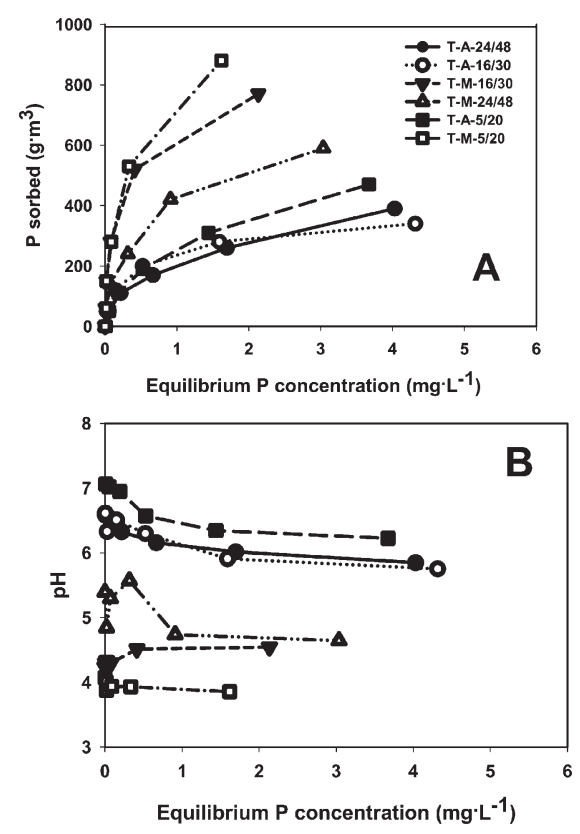

Fig. 1. $\mathrm{PO}_{4}-\mathrm{P}$ isotherms for Terra Green test materials (A) and $\mathrm{pH}$ of solution at various equilibrium $\mathrm{P}$ concentrations (B)
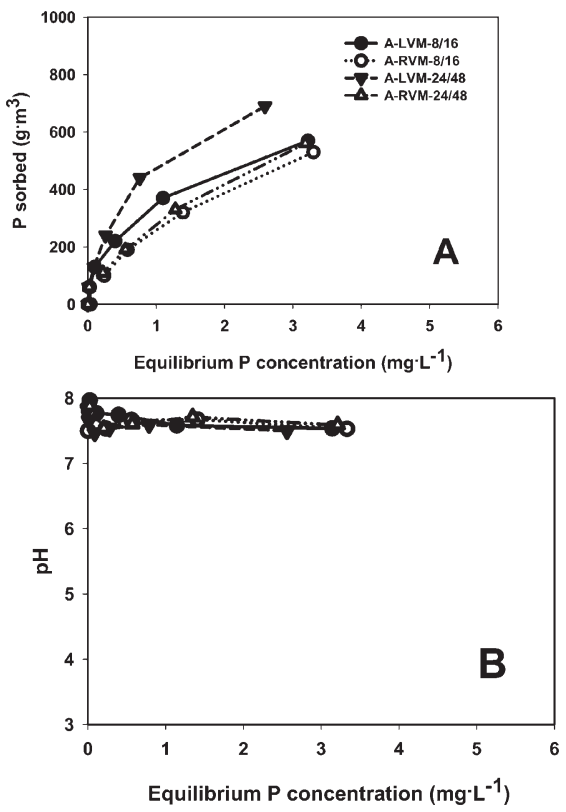

Fig. 2. $\mathrm{PO}_{4}-\mathrm{P}$ isotherms for Attasorb test materials (A) and $\mathrm{pH}$ of solution at various equilibrium $\mathrm{P}$ concentrations (B).

3A, and 4A). Using the parameter "a" from the Freundlich equation as a capacity factor, Terra Green montmorillonites had the highest $\mathrm{PO}_{4}-\mathrm{P}$ sorption (425 to $700 \mathrm{~g} \cdot \mathrm{m}^{-3}$ ). Terra Green attapulgites had lower $\mathrm{PO}_{4}-\mathrm{P}$ sorption ( 210 to $250 \mathrm{~g} \cdot \mathrm{m}^{-3}$ ) as shown in Table 3 and Figure 1A. Information obtained from the manufacturer of the Terra Green calcined materials indicated differences in the clays mined in Georgia versus Mississippi. The montmorillonites from Mississippi contained more $\mathrm{Fe}$, whereas the product mined in Georgia had higher magnesium and calcium content, which were capable of forming surface or solution precipitates with oxyanions. Differences in surface area may have influenced $\mathrm{PO}_{4}-\mathrm{P}$ sorption; however, the specific surface area provided by the suppliers ranged from $98 \mathrm{~m}^{2} \cdot \mathrm{g}^{-1}$ for Attasorb materials and 102 to $122 \mathrm{~m}^{2} \cdot \mathrm{g}^{-1}$ for Terra Green materials based on the standard Brunauer, Emmett and Teller procedure (Brunauer et al., 1938), which did not appear to be different enough to explain difference in $\mathrm{PO}_{4}$-P sorption.

Phosphate sorption levels of Terra Green materials increased with increasing initial $\mathrm{pH}$. The T-M-16/30 and T-M-5/20 had the highest sorption with the initial $\mathrm{pH}$ range of 3.8 to 4.0 , whereas T-A-16/30, T-A-24/28, and T-A-5/20 had comparatively lower $\mathrm{PO}_{4}-\mathrm{P}$ sorption with initial $\mathrm{pH}$ ranging from 5.6 to 6.2 (Table 3). The high $\mathrm{PO}_{4}-\mathrm{P}$ sorption under lower $\mathrm{pH}$ could have involved the dissolution of $\mathrm{Al}$ in the clay lattice in the formation of $\mathrm{AlPO}_{4}$ crystals. In acidic solutions, the mineral surface has a net $(+)$ charge, although both $(+)$ and $(-)$ sites exist. The predominance of $(+)$ charges readily attracts $\mathrm{H}_{2} \mathrm{PO}_{4}{ }^{2-}$ (Havlin et al., 2003).

The Attasorb LVM materials had higher $\mathrm{PO}_{4}$-P sorption ("a" $=320$ to $495 \mathrm{~g} \cdot \mathrm{m}^{-3}$ ) than Attasorb RVM materials ("a" $=220$ to 230 $\mathrm{g} \cdot \mathrm{m}^{-3}$ ) as shown in Table 3 and Figure 2A. Particle size played a part in enhancing $\mathrm{PO}_{4}$ $\mathrm{P}$ sorption in Attasorb LVMs with the smallest particle size having higher sorption than larger particle sizes. It was observed that RVM materials had a tendency to disintegrate into smaller particles when in solution compared with the LVM materials; therefore, the difference between the eventual surface area of RVM clay particles was not as great, which explained the lack of effect of particle size on $\mathrm{PO}_{4}-\mathrm{P}$ sorption. The LVM materials demonstrated better aggregate stability than RVM materials and would be preferred for use as soilless root medium components. Owen et al. (2007) compared the use of two temperature treatments (RVM and LVM) of a Georgian palygorskite-bentonite calcined clay at $8 \%$ by volume of a bark-based root medium; the mix with LVM clay leached $35 \%$ less $\mathrm{PO}_{4}-\mathrm{P}$ than the mix containing RVM clay.

The Terra Green attapulgites that originated from Georgia, T-A-5/20, T-A-16/40, and T-A-24/48, resulted in $\mathrm{PO}_{4}-\mathrm{P}$ sorption capacity, "a", of 250,240 and $210 \mathrm{~g} \cdot \mathrm{m}^{-3}$, respectively, showing no influence across these particle sizes on amount of $\mathrm{PO}_{4}-\mathrm{P}$ sorbed (Table 3). Ruter (2003) investigated the influence of three particle sizes of calcined clay (Sud-chemie, Meigs, GA) on $\mathrm{PO}_{4}{ }^{-}$ $\mathrm{P}$ retention. He concluded that particle size had limited influence on amount of $\mathrm{PO}_{4}-\mathrm{P}$ sorbed when particle sizes were greater than $3.36 \mathrm{~mm}$ and less than $1.00 \mathrm{~mm}$ (24/48 US mesh) and within the range of 1.00 to 3.36 $\mathrm{mm}(5 / 20$ and $16 / 30$ US mesh), 61\%, 76\%, and $74 \%$ reduction of $\mathrm{PO}_{4}$ leached occurred, respectively.

The slopes of the isotherms are indicators of buffer capacity with steeper slopes indi-
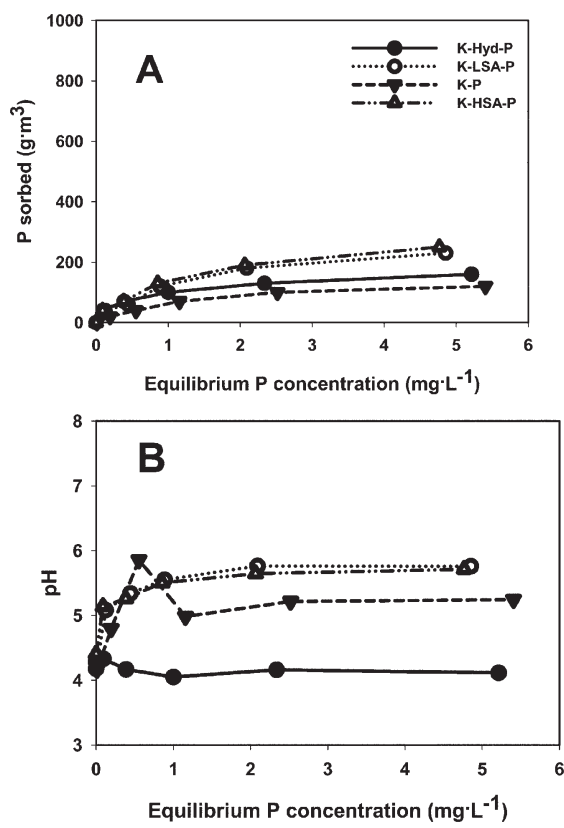

Fig. 3. The $\mathrm{PO}_{4}-\mathrm{P}$ isotherms for kaolin test materials (A) and $\mathrm{pH}$ of solution at various equilibrium $\mathrm{P}$ concentrations $(\mathbf{B})$.
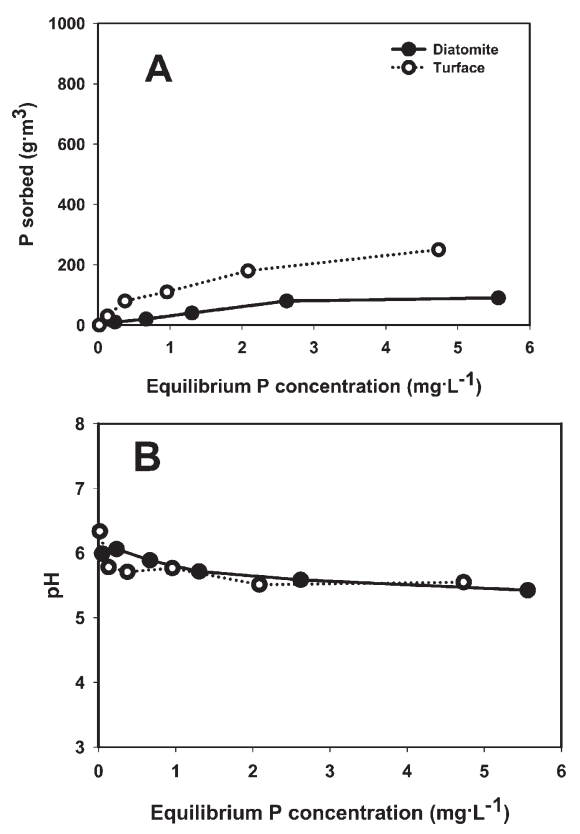

Fig. 4. $\mathrm{PO}_{4}-\mathrm{P}$ isotherms for diatomaceous earth and Turface test materials (A) and pH of solution at various equilibrium $\mathrm{P}$ concentrations $(\mathbf{B})$.

cating higher buffering capacity (Ozanne and Shaw, 1968). Such plots can be used to estimate the quantity of $\mathrm{P}$ to be applied to maintain the soil solution concentration at the desired level (Fox and Kamprath, 1970). Material with high $\mathrm{PO}_{4}-\mathrm{P}$ sorption like Terra Green montmorillonites continued to sorb $\mathrm{PO}_{4}-\mathrm{P}$ at even the highest levels of added $\mathrm{PO}_{4}-\mathrm{P}\left(200 \mathrm{mg} \cdot \mathrm{L}^{-1}\right.$; Fig. 1A). The higher $\mathrm{PO}_{4}-\mathrm{P}$ buffer capacity of these materials would necessitate greater $\mathrm{P}$ addition to achieve $0.2 \mathrm{mg} \cdot \mathrm{L}^{-1}$ soluble $\mathrm{PO}_{4}-\mathrm{P}$, which is considered optimum for most plants (Beckwith, 

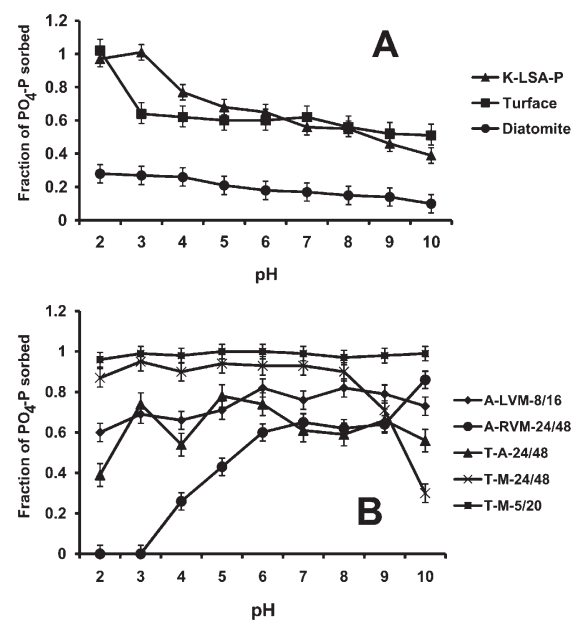

Fig. 5. Adsorption envelopes of $\mathrm{PO}_{4}-\mathrm{P}$ in suspensions containing $50 \mathrm{PO}_{4}-\mathrm{P} \mathrm{mg} \cdot \mathrm{L}^{-1}$ in $0.01 \mathrm{M}$ $\mathrm{KNO}_{3}$ solution for the various test materials (A-B). Sorption is expressed as the fraction of the average $\mathrm{PO}_{4}-\mathrm{P}$ adsorbed $\left(\mathrm{mg} \cdot \mathrm{kg}^{-1}\right)$ and maximum total $\mathrm{PO}_{4}-\mathrm{P}$ concentration $\left(\mathrm{mg} \cdot \mathrm{kg}^{-1}\right)$.

1965), but ensures that the level of soluble $\mathrm{PO}_{4}-\mathrm{P}$ is maintained for a longer period. As $\mathrm{PO}_{4}-\mathrm{P}$ is removed from solution by the plant, there would be a less dramatic change in intensity (root medium solution $\mathrm{PO}_{4}-\mathrm{P}$ concentration) in the more highly buffered media.

The buffer index from the slope of the Freundlich equation indicated that the kaolinite materials had very low buffer capacity ( 25 to $53 \mathrm{~L} \cdot \mathrm{m}^{-3}$; Table 3 based on Fig. $3 \mathrm{~A}$ ); they also had the lowest bulk density (Table 3 ). The kaolins are processed to achieve a low permeability, a property that would curtail sorption capability. Among the kaolin samples, K-HAS-P had the highest bulk density $\left(0.26 \mathrm{~g} \cdot \mathrm{cm}^{-3}\right)$ as shown in Table 3 .

The relatively low $\mathrm{PO}_{4}-\mathrm{P}$ sorption exhibited by Turface (Fig. 4A) could be as a result of high calcining temperatures of over $550{ }^{\circ} \mathrm{C}$ leading to the collapse of micro- and mesopores. Calcining temperatures play an important role in determining the sorptivity of the test materials.

Diatomaceous earth resulted in the lowest $\mathrm{PO}_{4}-\mathrm{P}$ sorption. If diatomaceous earth increased $\mathrm{PO}_{4}-\mathrm{P}$ retention after incorporation into soilless root media, the mechanism would not appear to be of a chemical nature.

$p H$. The $\mathrm{pH}$ of the supernatant after sorption remained fairly stable above the equilibrium concentration of $\approx 0.5 \mathrm{mg} \cdot \mathrm{L}^{-1}$ $\mathrm{PO}_{4}-\mathrm{P}$ for all test materials (Figs. 1B, 2B, $3 \mathrm{~B}$, and $4 \mathrm{~B}$ ). This was an indication that the calcined clays could help stabilize $\mathrm{pH}$ of soilless root media, which often contribute to problems of $\mathrm{pH}$ drift because of their poor buffer capacity. In peat-based soilless root media, lack of cation exchange capacity and base saturation of peatmoss had been implicated as contributors to $\mathrm{pH}$ drift phenomena (Rippy et al., 2005). However, calcined clays would need to comprise a significant volume of the total root medium to stabilize problems with $\mathrm{pH}$ drift during production.
Adsorption envelopes. The Attasorb RVM material sorbed more $\mathrm{PO}_{4}-\mathrm{P}$ with increasing $\mathrm{pH}$ with $0 \%$ sorbed at $\mathrm{pH} 2$ to 3 and up to $\approx 90 \%$ sorbed at $\mathrm{pH} 10 ; \approx 40 \%$ to $60 \%$ was sorbed at a $\mathrm{pH}$ range of 5 to 8 (Fig. 5B). The Attasorb LVM material, on the other hand, had $60 \%$ to $80 \%$ sorption over the $\mathrm{pH}$ range of 2 to 10, and the fraction generally increased as $\mathrm{pH}$ increased (Fig. 5B). The LVM materials (A-LVM-8/16, T-A-24/28) compared with an RVM material (A-RVM-24/ 28) showed yet another desirable characteristic of $\mathrm{pH}$ stability: sorption increased with increasing $\mathrm{pH}$ up to 6 , and no significant change in $\mathrm{PO}_{4}-\mathrm{P}$ sorption was observed from pH 6 to 9. Three possible mechanisms are proposed to explain the increasing $\mathrm{PO}_{4}-\mathrm{P}$ sorption with increasing $\mathrm{pH}$ exhibited by Attasorb: precipitation of $\mathrm{Ca}$ phosphates, Ca-induced $\mathrm{P}$ sorption, or coadsorption of $\mathrm{Ca}$ and $\mathrm{H}_{2} \mathrm{PO}_{4}^{-}$or $\mathrm{HPO}_{4}{ }^{2-}$ as ion pairs or complexes (Essington, 2004).

Terra Green montmorillonite of 5/20 mesh had a stable, high $\mathrm{PO}_{4}-\mathrm{P}$ sorption of $98 \%$ over the entire $\mathrm{pH}$ range, whereas the smaller particle size of this material, 24/28 mesh, had a high sorption fraction of $85 \%$ to $90 \%$ between $\mathrm{pH} 2$ and 8 with a sharp decrease in sorption after $\mathrm{pH} 8$ to approximately only $20 \% \mathrm{PO}_{4}-\mathrm{P}$ sorption at $\mathrm{pH} 10$ (Fig. 5B).

Turface had a stable $\mathrm{PO}_{4}-\mathrm{P}$ sorption of $\approx 60 \%$ over the $\mathrm{pH}$ range of 3 to 10 (Fig. $5 \mathrm{~A}$ ). Diatomaceous earth had a small fraction of $\mathrm{PO}_{4}-\mathrm{P}$ sorbed $(15 \%$ to $30 \%)$, which decreased with increase in $\mathrm{pH}$. Low surface area metakaolin (K-LSA-P) had a high $\mathrm{PO}_{4}-\mathrm{P}$ sorption of $98 \%$ at $\mathrm{pH} 2$ and 3, which decreased with increasing $\mathrm{pH}$ to $40 \% \mathrm{PO}_{4}-\mathrm{P}$ adsorbed at $\mathrm{pH} 10$ (Fig. 5A).

The adsorption envelopes indicate that $\mathrm{pH}$-dependent charge of the calcined materials is not a critical mechanism of $\mathrm{PO}_{4}-\mathrm{P}$ sorption in greenhouse production. Laboratory results from various calcined clays demonstrate that the mechanism by which $\mathrm{PO}_{4}-\mathrm{P}$ attaches to the surface of a calcined material is generally not $\mathrm{pH}$-dependent within the $\mathrm{pH}$ ranges of 5.0 to 7.0 maintained during container production.

Degree of phosphorus saturation. The DPS was calculated using the ratio of M3 $\mathrm{PO}_{4}-\mathrm{P}$ to the experimentally determined PSI (Bache and Williams, 1971; Pote et al., 1999; Sims et al., 2002; Table 3). The DPS of the calcined materials generally suggested that they possess significant capacity to sorb $\mathrm{PO}_{4}-\mathrm{P}$ with DPS less than $7.7 \%$ for all materials except two of the 1:1 kaolinites (Table 3). The low STP and high PSI values associated with several of the calcined materials, namely Attasorb LVM and Terra Green attapulgites and montmorillonites, suggest that a large quantity of vacant sites exist for $\mathrm{PO}_{4}-\mathrm{P}$ sorption.

In summary, several of the calcined materials that we characterized could be used as a component of soilless media to decrease $\mathrm{PO}_{4}$-P leaching. Results of isotherm and DPS calculations indicated that the most promising materials were Terra Green montmorillonites and attapulgites and Attasorb LVM attapulgites. The least promising materials were diatomaceous earth and kaolinites. The $\mathrm{PO}_{4}-\mathrm{P}$ adsorption envelopes indicated that $\mathrm{PO}_{4}-\mathrm{P}$ sorption was not strongly $\mathrm{pH}$ dependent within the $\mathrm{pH}$ range of commercial production, indicating that $\mathrm{pH}$-dependent charge is not a critical means of $\mathrm{PO}_{4}-\mathrm{P}$ retention during greenhouse production. Calcining temperature affected optimal $\mathrm{PO}_{4}-\mathrm{P}$ sorption: LVM attapulgites had better sorption than the RVM attapulgites that were calcined at lower temperatures, but Turface, which is also a 2:1 clay and calcined at a very high temperature, did not match the $\mathrm{PO}_{4}-\mathrm{P}$ sorption potential of LVM Attasorb and LVM Terra Green attapulgites. Finally, the high level of native total $\mathrm{P}$ in some of the materials may provide some $\mathrm{PO}_{4}-\mathrm{P}$ as fertilizer to crops.

Benefits of using calcined materials beyond $\mathrm{PO}_{4}-\mathrm{P}$ retention may include increased water retention because the calcined products have significant moisture sorption properties, which are related to their primary commercial use as absorbents. The temperatures of calcining are crucial in determining the extent to which the hardened aggregates maintain internal porosity.

Limitations of using calcined products as soilless root medium components include the high cost of purchase and shipping, especially if used at high enough percentages in soilless root media to impart adequate benefit such as buffering against $\mathrm{pH}$ drift. Because the materials are mined, natural variability occurs at different mines and even mining depths within the same mine; this would contribute to lack of uniform and consistent quality attributes in the materials. Finally, if calcined materials with very high $\mathrm{PO}_{4}-\mathrm{P}$ sorption capacity are used, the materials themselves may remove $\mathrm{PO}_{4}-\mathrm{P}$ from root medium solution when used in tandem with very low rates of $\mathrm{PO}_{4}-\mathrm{P}$ fertilization.

Future research should investigate optimal percentages of incorporation of calcined products into soilless media, especially under conditions of greenhouse production. The mechanism of $\mathrm{PO}_{4}-\mathrm{P}$ sorption by the calcined materials is ambiguous and further research could elucidate these mechanisms. Phosphate desorption of the materials should be further evaluated. Finally, the economic benefits of reduced $\mathrm{PO}_{4}-\mathrm{P}$ runoff in greenhouse effluent and reduced water use during production should be evaluated to help growers make decisions about using calcined materials.

\section{Literature Cited}

Aslam, M., M.S. Zia, Rahmatullah, and M. Yasin. 2000. Application of Freundlich adsorption isotherm to determine phosphorus requirement of several rice soils. Intl. J. Agr. Biol. 2:286288.

Bache, B.W. and E.G. Williams. 1971. A phosphorus sorption index for soils. J. Soil Sci. 22:289-301.

Beckwith, R.S. 1965. Sorbed phosphate at a standard supernatant concentration as an estimate of the phosphate needs of soils. Aust. J. Exp. Agr. Anim. Husb. 5:52-58. 
Bender, M.R. and C.W. Wood. 2000. Total phosphorus in residual materials, p. 77-82. In: Pierzynski, G.M. (ed.). Methods of phosphorus analysis for soils, sediments, residuals, and waters. Southern Cooperative Series Bull. No. 396.

Bray, H.J., S.A.T. Redfern, and S.M. Clark. 1998. The kinetics of dehydration in Ca-montmorillonite: An in situ x-ray diffraction study. Mineral. Mag. 62:647-656

Bremner, J.M. and C.S. Mulvaney. 1982. Salicylic acid thiosulfate modification of the Kjeldhal method to include nitrate and nitrite, p. 621. In Miller, R.H. and D.R. Keeney (eds.). Methods of soil analysis. Part 2. Amer. Soc. Agron., Madison, WI.

Brunauer, S., P.H. Emmett, and E. Teller. 1938. Adsorption of gases in multimolecular layers. J. Amer. Chem. Soc. 60:309-319.

Bugbee, G.J. and G.C. Eliott. 1998. Leaching of nitrogen and phosphorus from potting media containing biosolids compost as affected by organic and clay amendments. Bull. Environ. Contam. Toxicol. 60:716-723.

Catanzaro, C.J. and S.M. Bhatti. 2005. Incorporated substrate amendments to reduce water use in poinsettias. Proc. S.N.A. Res. Conf. 50:37-38.

Catanzaro, C.J., S.M. Bhatti, and R. Kamake. 2004. Incorporation of clay amendments to reduce fertilizer use in poinsettias. Proc. S.N.A. Res. Conf. 49:34-36.

Chapman, H.D. and P.F. Pratt. 1961. Methods of analysis for soils, plants, and waters. Univ. Calif., Div. of Agr. Sci. p. 169-170.

Chaudhry, E.H., A.M. Ranjha, M.A. Gill, and S.M. Mehdi. 2003. Phosphorus requirement of maize in relation to soil characteristics. Intl. J. Agr. Bio. 5:625-629.

Essington, M.E. 2004. Soil and water chemistry. CRC Press, New York, NY.

Fox, R.L. and E.J. Kamprath. 1970. Phosphate sorption isotherms for evaluating the phosphate requirements of soils. Soil Sci. Soc. Amer. Proc. 34:903-906.
Handreck, K. and N. Black. 2002. Growing media for ornamental plants and turf. 3rd Ed. UNSW Press, Sydney, Australia.

Havlin, J.L., J.D. Beaton, S.L. Tisdale, and W.L. Nelson. 2003. Soil fertility and fertilizers: An introduction to nutrient management. 7th Ed. Pearson/Prentice Hall, Upper Saddle River, NJ.

Hillel, D. 2004. Introduction to environmental soil physics. Elsevier Academic Press, Amsterdam, The Netherlands.

Le Mare, P.H. 1982. Sorption of isotopically exchangeable and non-exchangeable phosphate by some soils of Colombia and Brazil, and comparisons with soils of Southern Nigeria. J. Soil Sci. 33:691-707.

Marconi, D.J. and P.V. Nelson. 1984. Leaching of applied phosphorus in container media. Sci. Hort. 22:275-285.

Moll, W.F. and G.R. Goss. 1997. Mineral carriers for pesticides - Their characteristics and uses. Standard Technical Publication 943. Amer. Soc. Testing and Materials, West Conshohocken, PA.

Murphy, J. and J.P. Riley. 1962. A modified single solution method for the determination of phosphate in natural waters. Anal. Chim. Acta 27:31-36.

Nelson, P.V. 2005. Greenhouse operation and management. 6th Ed. Prentice Hall, Upper Saddle River, NJ.

Noyan, H., Ö. Müserref, and Y. Sarikaya. 2006. The effect of heating on the surface area porosity and surface acidity of a bentonite. Clays Clay Miner. 54:375-381.

Obaid-ur-Rehman, A.M., R. Ranja, M.A. Gil, and S.M. Mehdi. 2004. Phosphorus requirement of wheat using modified Freundlich model in Rasulpur soil series. Pak. J. Agr. Sci. 41:1-2.

Owen J.S., S.L. Warren and T.E. Bilderback. 2003. Amending pine bark substrate with clay to increase nutrient and water efficacy. The North Carolina Association of Nurserymen, November/December.

Owen, J.S., S.L. Warren, T.E. Bilderback, and J.P. Albano. 2007. Industrial mineral aggregate amendment affects physical and chemical properties of pine bark substrates. HortScience 42:1287-1294.

Ozanne, P.G. and T.C. Shaw. 1968. Advantages of the recently developed phosphate sorption test over the older extractant methods for soil phosphate. In: Transactions of the 9th International Congress of Soil Science, Adelaide, Australia. Intl. Soc. of Soil Sci. 2:273-280.

Parfitt, R.L. 1978. Anion adsorption by soils and soil materials. Adv. Agron. 30:1-50.

Pote, D.H., T.C. Daniel, D.J. Nichols, A.N. Sharpley, P.A. Moore, D.M. Miller, and D.R. Edwards. 1999. Relationship between phosphorus levels in three ultisols and phosphorus concentrations in runoff. J. Environ. Qual. 28:170-175.

Rippy, J., P. Nelson, and T. Bilderback. 2005. Factors affecting $\mathrm{pH}$ establishment and maintanance in peat moss based substrates. HortScience 40:1124. (abstr.).

Ruter, J.M. 2003. Calcined clay reduces phosphorus losses from pine bark substrate. Proc. S.N.A. Res. Conf. 48:84-87.

SAS Institute. 2002. SAS/STAT, Version 9.1. SAS Institute, Inc., Cary, NC.

Sen Tran, T. and R.R. Simard. 1993. Mehlich IIIextractable elements, p. 43-49. In: Carter, M.R. (ed.). Soil sampling and methods of analysis. Lewis, Boca Raton, FL.

Sharpley, A.N. 1995. Dependence of runoff phosphorus on extractable soil phosphorus. J. Environ. Qual. 24:920-926.

Sposito, G. 1980. Derivation of the Freundlich equation for ion exchange reactions in soils. Soil Sci. Soc. Amer. 44:652-654.

Sims, J.T., R.O. Maguire, A.B. Leytem, K.L. Gartley, and M.C. Paulter. 2002. Evaluation of Mehlich 3 as an agri-environmental soil phosphorus test for the mid-Atlantic United States of America. Soil Sci. Soc. Amer. J. 66:2016-2032.

U.S. Environmental Protection Agency. 1984. Methods for chemical analysis of water and wastes. EPA-600/4-79-020. U.S. Environmental Protection Agency, Cincinnati, $\mathrm{OH}$ 